\title{
スポーツ人類学専門分科会研究活動の回顧と展望
}

\author{
寒川 恒夫
}

\section{Review on research activities of the Sport Anthropology Section of JSPHSS}

\author{
Tsuneo Sogawa
}

\section{Key words : perspectives}

\section{(Japan J. Phys. Educ. Hlth. Sport Sci. 50: 235-241, March, 2005)}

キーワード：研究史

\section{Iはじめに}

スポーツ人類学専門分科会は, 1988 年 10 月 2 日に福島大学で開かれた日本体育学会第 39 回大 会総会において設置が承認された。以来，今日に 至る16年間の活動は，これを，1）学会大会にお ける一般研究発表・シンポジウム・キーノートレ クチャー，2）合同フィールドワーク，3）国際学 術会議，4）専門分科会誌『スポーツ人類学研究』 の発行，に分けられる。

これら 4 つ活動がどのような内容であったの か，その具体を記すことから始めよう。

\section{II 学会大会における活動}

1）学会大会時の一般研究発表は, 以下のテー マのものであった.

・第 40 回大会（1989年）

夕イ舞踊の構造と技法に関する研究一プレン・ チャー・プレン・レウの女型を中心に一、神がか り舞踊の運動表現一山口県阿武郡吉部野下の「厄

早稲田大学スポーツ科学部

テ 359-1164 埼玉県所沢市三ヶ島 2-579-15

連絡先 寒川恒夫
神舞」を事例として一・ヒマラヤの王国・ラマ僧 の舞. 祭礼競技一船競漕（I）一山口県北浦地域 一。バスク地方の民族スポーツに関する研究。才 リンピック競技成績の地域別比較一特にヨーロッ パ地域を中心として一.「民族競技」としての 「綱引」の事例研究一鹿児島県薩摩郡䲡島列島を 中心として一，二風谷アイヌの夏の遊び一エス ノ・サイエンスの立場から一。 大門の伝承相撲一

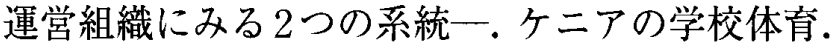
夕イ人と日本人の投能力の比較研究一夕イ東北地 域（ウボンラチャタニー県）における発育・発達 調査第 12 報一. 生活の都市化と子どものスポー ツ遊びについて一タイ国ウボン県を事例として 一. 浅草オペラから浅草レビューへの変遷におけ る舞踊性と身体性.アフリカの舞踊地図作成試論.

・第 41 回大会（1990年）

アジア亜大陸におけるラマルのサイコロ起原説 について. モへンジョ＝ダーロにおける水中活動 について．アフガニスタンの騎馬競技について. 約婚球戯から投綉球へ一中国民族スポーツの変容 事例一。鳥取県三朝の綱引き行事。「エンピツま わし」の研究一伝播の条件一. 祭礼競技一船競漕 （II）一壱岐勝本浦を中心に一，民俗芸能と伝承.

School of Sport Sciences, Waseda University

2-579-15, Mikajima, Tokorozawa, Saitama, 359-1164, Japan

Corresponding author sogawa@waseda.jp 
ダンス・ホールのダンサーに関する一考察。日本 の五大弁財天にみる身体観について。日本の民俗 医療体系にみられる「治療体操」について一操体 を一例として一，体育科授業の進め方に関する研 究一海外帰国生の教育体験を通しての比較検討

・第 42 回大会（1991 年）

ガンダーラの飛天にみる泳ぎ。ペルシアの古典 カ技.アフガニスタン北部の騎馬競技と騎馬文化. ユーゴスラヴィアのフォークダンスについて．夕 イ国ウボン県における伝統遊びの動態。闘鶏と中 国文化. 台湾山地族の健康に関する研究一Rukai 族女性について一，民俗スポーツの文化領域設定 の試み一クラスター分析の利用方法一、日本にお ける伝統的『医療体術』に関する研究一調和道丹 田呼吸法について一，祭礼競技（III）一新宮市 御舟祭・古座町河内祭の船競漕一。童相撲」に 関する一考察一文化伝播の問題を中心として一. 雪国の冬季に招ける子どもの運動（スポーツ）遊 びについて一幼児の事例調查から一。ヒトの進化 過程における投擲動作の起源について。

・第 43 回大会（1992年）

野球の文化人類学的アプローチ．新聞記事に見 る戦後の阿波踊り一演舞場の成立を中心に一。祭 礼競技 (IV) 対馬の舟競漕一その 1 - 競漕形態一。 春祭における「銁引き」について一鹿児島県大隈 半島を中心にして一，北九州地方における女相撲 について一長崎祡・佐賀県の場合一。能登地方に おける伝承相撲についての研究一唐戸山相撲を中 心とする能登地方の伝承相撲の階層制について 一。間之原地蔵奉納相撲の実態一 1885 年から 1967 年までの開催経費の検討を通して一。トル コの古代遺跡にみる水と身体活動．パダング族に みる健康法一ミャンマーの特異な少数民族の小村

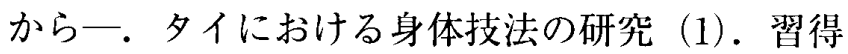
方法からみたタイ国ウボン県における子どもの遊 びの地域差.

・第 44 回大会（1993年）

八つ鹿踊りの鹿面に関する一考察一愛媛県城川 町の八つ鹿踊りを事例として一. 対馬の舟競漕一 その 2. 舟競漕の周辺一. 1920 年代の軽演劇の変
遷に関する一考察一変遷の検証と男性舞踊手の事 例一. 韓国シャーマンの身体科学的研究一憑霊時 の心身の変化を中心として一. 生殖崇扯における 「水」の役割.「統一」サンサ踊りの社会的構成一 「地域文化の再・創出」として一，沖縄における エイサーの踊り手と踊りの場の相互関係につい て. 新聞記事に見る戦後の阿波踊り一戦後の阿波 踊りを支えたもの一. ユーラシア大陸の古代スキ 一研究・3一モンゴル国少数民族ツァータン（ト ウワー）の毛皮スキーについて一，伝統遊びの国 際比較。

\section{·第 45 回大会（1994年）}

世代別にみたタイ国ウボン県の子どもの遊びの 変容. 牛追いの世界観一パンブローナのエンシエ ロ一．戦後の阿波踊りに見られる美的構成．浅草 オペラに扮ける女性舞踊家（振付師・ダンサー） の特性．沖縄の民族舞踊「エイサー」の構成分析 一勝連町平屋敷のエイサーを事例として一。沖縄 の祭祀舞踊における上肢運動の特性一本部町の 「しぬぐ舞」を中心に一。全員参加型祭礼・新潟 県小千谷市「片貝まつり」にみる大型花火志向と その祭礼構造. 創られた伝統スポーツ一波戸の海 中綱引を事例として一.

・第 46 回大会（1995 年）

熊野・二木島の舟競漕.「ハマ投げ」に関する 研究一南九州を中心として一.「なもで踊り」復 元の試み一奈良県安堵町の事例を中心として一。 オーストラリア柔道人のスポーツ観. トン族相撲 祭の社会的機能一中国貴州省壮黎平県坑洞の口頭 伝承一. 1920 年代の浅草の大衆文化に打ける女 性ダンサー一浅草オペラの女性ダンサーに関する 一考察—.

・第 47 回大会（1996年）

インドネシアの「競牛レース」に関する研究. ネパールの遊戯に関する一考察。韓国ムダンの意 識状態.オーストラリア柔道人のスポーツ観一そ の 2 一. イヌクジュアク・イヌイットの民族遊戯 の変容.「卯之刻相撲」の構造と変化一神事相撲 存続の一形態一，沖縄本島におけるエイサーの隆 盛を支えるもの一民俗舞踊の変化を肯定する伝統 一. 牛の角突きの習俗一文化の伝統と変容の問題 
一. 1920 年代の浅草の大采文化における女性ダ ンサー一浅草レビューの女性ダンサーに関する一 考察一. なもで踊りの研究一「布留社南無手踊」 をめぐって一. 阿波踊りの起源について．蛇綱行 事にみる龍蛇神信仰とその表現一関東三地域の蛇 綱行事を事例として一，瀬戸内の舟競漕一瀬戸 内・芸予の櫂伝馬一。

・第 48 回大会（1997 年)

越後の獅子舞一文化の伝承と変容の問題一。浅 草レビューの女性ダンサーと舞踊一女性ダンサー の容姿・技術と舞踊一. 琉球古典舞踊「女踊り」 における上肢動作の特性一伝承言語の分析を手が かりに一.「シマの踊り」から「沖縄の踊り」へ 一戦後の沖縄におけるエイサーの変化一。菊間の お供馬（その1）一賀茂競馬とお供馬の関係につ いて一．菊間のお供馬（その2）一祭りの組織基 盤一. 菊間のお供馬（その3）一運営システムに ついて一. バスク地方のボウリング一競技特性と しての「武」一. 体育的価值からみた子どもの遊 びの変容一タイ国ウボンラーチャター二県におけ る子ども遊び調査を事例として一. モンゴル相撲 の技の研究. 伝統競技の近代化に関する一考察伝統的舟競漕にみる近代化一, 網引きの構造と変 容一京都府相楽郡精華町について。福岡県築上郡 吉富町八幡古表神社の神相撲一。日本における葬 礼相撲一地蔵信仰と祖先祭祀一。

・第 49 回大会（1998年）

エチオピアの民族舞踊. 戦後の沖縄におけるエ イサーの展開一「みる／みられる」民俗舞踊の普 及一、映画館のアトラクションの女性ダンサーに 関する一考察。伝統競技におけるバイオレンスの 変容一沖縄県南風原町の綱引きを事例として一. 韓国の民族スポーツに見る文化変容一全国民俗芸 術競演大会を通して一，「伝統スポーツ」の歴史 的背景一ハイランド・ゲームの場合一、フォーク ダンスサークルにおける組織と会員のネットワー ク（その1）-「練馬区 K フォークダンス友の会」 の組織構造を中心として一.フォークダンスサー クルにおける組織と会員のネットワーク（その 2) 一「練馬区Kフォークダンス友の会」の会員の 動向を中心として一.
・第 50 回大会 (1999年)

セヤ川下り大会の沿革一創始者のロマン一、ド イッ伝統球技一Turnspiel一について 第 1 報 Turnspiel の歴史. 1980 年代における夕イ国子ど もの伝統遊戯とスポーツ. PENCAK SILATにお ける身体技法体系. アイヌの身体観に関する研究 一アイヌ語基礎語彙の言語人類学的分析を通して 一・「ッキ」のスポーツ人類学—民俗世界と近代 スポーツの接点一.アジアの伝統芸能にみる運動 表現の民族的特性一韓国仮面劇「固城五広大」の 様式性と運動表現の特徵一. 身体表現としての仏 舞研究，わたしたちにとって「おどり」とはなに か-ICU 日本民俗舞踊実技授業 30 年の成果一. 戦後の沖縄における興奮の探求一民俗舞踊の競技 化と普及の過程一. 芸能の<競争 $>$ と<育成 $>の$ 立場から見た阿波踊り。狂言における呼吸技法一 大蔵流山本家の「附子」を中心に一。地唄舞（上 方舞）の社会組織一閑崎流名取式にみる家元制度 を事例として一。

・第 51 回大会 $(2000$ 年)

文化装置としての遊び一カナダにおける宗教的 少数民族フッタライトの事例一. ドイッ伝統球技 一Turnspiel一について 第2 報 Prellball. 古 代エジプト・セド祭にお扔ける走行儀礼に関する一 考察. 五島列島にみる綱引の文化変化. 沖縄の民 俗舞踊「エイサー」の芸態分析. 京都府舞鶴市松 尾寺の仏舞にみる舞踊構造.

・第 52 回大会 (2001 年)

伝統スポーツを媒介とした地域祭にみる門中ア イデンティティ一韓国忠清南道唐津郡における南 以興将軍崇慕祭を通して一。ナイル川流域におけ る現代・古代レスリングについて一スーダン以北 地域の現代 - 古代事例の比較研究一. Gret Palucca一その舞踊観・教育観に関して一. インド舞 踊（パラタナーティアム）を構成しているステッ プとジェスチャーとの割合.「文化の伝播」から 見た蹴鞠に関する一考察. 子どもの遊びにみる文 化化一宗教的少数民族フッタライトの事例一.

・第 53 回大会 (2002 年)

ショースポーツとしての江戸時代の相撲興行に ついての一考察一勧進相撲と見世物女相撲の比較 
から一、ムエタイのスタジアムにおける社会階層. 宮崎県西都市銀鏡（しろみ）の的射（まとい）の 変容について．わが国の舟競漕の現状と課題. 韓 民族武芸のテッキョンにみる柔道の技と理念。権 力装置としての民族スポーツーモンゴル国のナー ダムを事例として一. Gret Palluca一戦後の舞踊 活動に関して一。バラタナーティアム（インド舞 踊）のハス夕（手による表現動作）における自己 組織化臨界現象一ジュテイシュワラム曲における ハスタの出現頻度とそのランクからとらえた関係 一。古代ギリシャに打ける葬送競技（agon epitaphios）の質的変化. アイヌ語の上肢に関する 語彙にみる自然認識と分岐のイメージ一当該言語 による動きの記述に関する試論一，民族スポーツ の概念化. ゴトランドの民族スポーツに関わる組 織の変容. 多文化主義における民族スポーツの位 置づけ一カナダ・アルバータ州の事例一.

\section{·第 54 回大会（2003年）}

日本の民話・怪談にみる化物との相撲・格闘. 豊穣儀礼としての舟競漕一沖縄県西表島・祖内の 事例から一。火神祭りにおける攻防戦について 一熊本県天水町小天の事例一. プユマの伝統行事 にみる民族スポーツー中華民国台湾・台北市知本 の収穫祭を事例として一. スポーツ人類学専門分 科会の研究状況の足跡. ナイジェリア国立劇場と 国立舞踊団.日本の民俗舞踊とその教育効果一民 俗舞踊を学習することによって学習者は何を得た か一. 静岡県森町小國神社の十二段舞楽における 「色香」の舞踊特性一演者と観客の体験を手がか りとして一，鹿児島県疮瘡踊りの表現特性一動作 分析を中心として一. 地域スポーックラブの地域 密着性に関する一考察一SCC（スポーツ・コミ ユニケーション・サークル）を事例として一。ヴ アルパにみるスウェーデン本土とゴトランドの関 係.エジプト・アラブ共和国上エジプト地方にみ る en-nabbutについて. プンチャック・シラット の精神文化.

\section{・第 55 回大会（2004年）}

我が国における近代テニスの受容の特徵一男性 性の鼓舞の側面について一。ムエタイの儀礼にみ られる宗教と選手の立場一闘いの舞いに表れるム
エタイ選手の姿一. 古代アテネのトーチレース （Lampadedromia）に関する一考察一.八重山地 万ハーリーの観光化に伴う変容. 台湾原住民の民 族スポーツープュマ（杽南族）を事例として一。 ナッブートの持つ文化装置としての機能につい て.インド・ケーララ州のテイヤム Teyyam と カラリパヤットKalarippayattu. ムカレカレにみ るトゥンガナンの適応戦略.

2）学会大会時のシンポジウムおよびキーノー トレクチャーのテーマは以下のようであった.（s) はシンポジウム，（k）はキーノートレクチャー を示す。

・第 40 回大会（1989 年）

(s) スポーツ人類学の課題と展望

・第 41 回大会（1990年）

(s) 網引の人類学

・第 42 回大会（1991 年）
(s) 相撲の人類学
(s) 舞踊の人類学

・第 43 回大会（1992 年）
(s) 競馬の人類学
(s) 舞踊の人類学 (第 2)
（s）相撲の人類学（第 2）一日本の相撲の文化 的多様性

・第 44 回大会（1993年）
（s）舞踊の人類学（第 3）ートランスと舞踊一
(s) サッカーと野球の人類学

・第 45 回大会（1994 年）

(s) 国際スポーツ柔道の人類学一カラー柔道着 の問題周辺一
（s）舞踊の人類学（第 4)一手と足の動作特性一 ・第 46 回大会（1995年）

(s) 舞踊の人類学（第 5 )

（s）国民体育大会の人類学

・第 47 回大会（1996 年）

（k）フィールドワークの方法論

(s) 賭とスポーツの人類学

(s)「舞」と「武」の人類学

・第 48 回大会（1997 年）

（k）スポーツ人類学の語り方一民族誌を書 


\section{$<-$}

（s）スポーツとエスニシティー

（s）舞踊伝承の人類学一技の伝承をめぐって一 ・第 49 回大会（1998年）

（k）バスク民族スポーツのフィールドワーク

（s）民族スポーツの社会組織

(s) スポーツ的身体技法

・第50 回大会（1999年）

（k）ダンスのフィールドワークーその成果と 還元をめぐって一

（s）朝鮮半島のスポーツ文化

（共催 s）日本人とスポーツ文化

・第 51 回大会 (2000年)

（k）子ども遊びのフィールドワーク

（s）植民地経験とスポーツ文化

・第 52 回大会 (2001 年)

（k）インドネシア民族スポーツ研究の現状と 課題

(s) Futbolistico!：サッカーの人類学 サッカ 一・汀・終わらない 20 世紀?

（s）舞踊文化の伝承としての教授

・第 53 回大会 (2002年)

(k) 琉球舞踊における技法研究の課題と展望 一アジア太平洋地域舞踊の比較研究のために一

（s）文化政策としての民族スポーツ

・第 54 回大会（2003 年）

（k）“遊び”の民族誌を書く：フィールドワー カーのまなざし

（s）民族舞踊と教育プログラム

・第 55 回大会（2004年）

（k）アイヌ語身体名称にみる身体観一自然認 識と身体の幹一

（s）エスニック・スポーッと教育プログラム

\section{III 合同フィールドワーク}

スポーツ人類学はその主要な情報収集をフィー ルドワークに求めるところから，分科会ではその 方法論を共有することを目的として毎年度国内と 国外とにおいて合同フィールドワークを催してき た。その状況は以下の通りである．開催年月日，
調査行事名（場所）を示す.

1990 年 1 月 $20 \cdot 21$ 日, 祝園神社「いごもり祭」

の綱引神事（京都府相楽郡精華町）

1991 年 11 月 $11-18$ 日, 第 4 回中国少数民族伝 統体育運動会（中国広西壮族自治区南寧）

1993 年 6 月 $23 \cdot 24$ 日, 江陵端午祭（韓国江原 道汇陵)

1994 年 6 月 $3-5$ 日，厳島神社大祭和船競漕才 シクラゴウ（山口県萩市玉江浦）

1995 年 11 月 $5-13$ 日, 第 5 回中国少数民族伝 統体育運動会（中国雲南省昆明市）

1996 年 8 月 $3 \cdot 4$ 日, 八幡古表神社古式人形神 相撲（福岡県築上郡吉富町）

1997 年 9 月 $1-8$ 日，バリ島民族舞踊・民族ス ポーツ（インドネシア共和国バリ島）

1999 年 1 月 15 - 17 日, ヘトマト（長崎県福江 市)

2001 年 9 月 7 日一 14 日，台湾民族スポーツ （台湾台北市）

\section{IV 国際学術会議}

国際学術会議は上述した合同フィールドワーク のうち海外で実施した機会に当地研究機関と共同 に開催したものである。その内容は以下の通りで ある.開催年月日，学術会議名（開催地）を示す. 1991 年 11 月 $6-8$ 日, 日中スポーツ人類学シ ンポジゥム (中国上海市，上海体育大学)

1993 年 6 月 $20 \cdot 21$ 日，日韓民族スポーッシン ポジウム (韓国ソウル市, 中央大学)

1995 年 11 月 5 -8 日，中国民族スポーツ国際 会議（中国雲南省昆明市，昆明体育運動委員会） 2001 年 9 月 $8-13$ 日, 第 1 回日中韓スポーツ人 類学国際シンポジウム（台湾台北市, 国立台北師 範大学)

\section{V 分科会誌}

分科会による研究誌の発行は分科会設立当初か ら望まれていたが，諸条件が整って第 1 号が出版 されたのは 1996 年度であった。誌名は『スポー 
ツ人類学研究』とし, 論文は原著論文と研究情報 とに分けて寄稿を受けつけ，いずれも編集委員会 の審査を経て揭載が決定される規定であった。分 科会誌の発行は，しかし，2号で終わっている. 分科会員の多くが参加した独立学会「日本スポー ツ人類学会」が1998年に設立され，学会誌『ス ポーツ人類学研究』創刊号の発行を機に, 分科会 誌の廃刊が分科会総会において決定されたのであ る.以後, 分科会は日本スポーツ人類学会と, 合 同フィールドワークや国際会議の開催などについ て情報と意見を交換する関係を有している。

\section{VI まとめと展望}

学会大会一般研究発表のテーマを通観すると, 初期においては「ヒトの進化過程における投擲動 作の起源について」など自然人類学的発表もおこ なわれたことが知られる。これはスポーツ人類学 の “人類学”をどう理解するかという根幹に関わ る問題でもある.人類学は，日本語としては，そ れはもっぱら自然人類学を指すと理解するのが明 治以来の伝統であった. しかし，人類学の原語で ある anthropologyは anthropos（人）とlogos （学）の合成語であって人に関わる総合的理解を めざしているとするいわゆる general anthropologyの立場からすれば, 自然人類学と文化人類学 の双方を含めることになる。

スポーツ人類学専門分科会は当初 general anthropologyの立場をとったものの，その後は文 化人類学の性格を強めているといえよう。この状 況はアメリカにおいても同様であり，1985年に The anthropology of sportを出版したBlanchard とCheskaは同書でこの点に言及している，自然 人類学の中でも例えば直立二足歩行の形成過程の 研究は人類の諸種の動作の進化問題と関わり，ま た霊長類の遊び研究は人類の遊び行動や競争行動 の発生問題を導くなど，スポーツ人類学に極めて 有益な示唆を与えてくれる. 自然人類学の情報を 文化の問題，それもスポーツと関わる文化の問題 として展開する豊かな着想が待たれるのである.

一般研究発表が対象とした民族や地域について
は，相当に顕著な傾向が見えている．関係のある 160 件の発表のうち $57 \%$ 日本であり, 東アジア は $8 \%$, 東南アジア・インド・中近東は $19 \%$, ヨーロッパは $10 \%$, アフリカは $5 \%$ となってい る. 南北アメリカはカナダが数件，オセアニアは オーストラリアが数件であり，研究はその過半が 日本について展開する。これは日本人研究者にと って日本国内の問題こそがより身近でより重要で あるという認識に出るものであり，そうした自国 文化研究傾向は日本に限ったことではない.しか しこうした地域研究は, 他方において, 通文化 的・通地域的な比較研究を必要とする．比較によ って特定地域の研究は全体の中の位置づけと,こ れにともなう新しい研究着想を手に入れることに なるからである．全体に展望を与えるそうした比 較研究の出現が今後大いに待たれるのである.

一般研究発表が扱ったテーマはさまざまである が，競技や遊びに対し舞踊が相対的に多いのも特 徵といえる.そして，そうした競技なり舞踊なり を表示するのには，それぞれの土地の人達が用い る言葉を使う場合（例えば沖縄のエイサーや鹿児 島の鈎引き）もあれば，研究者が造語する場合 （例えば中国チワン族の約婚球戯）もあり，さま ざまである．この場合，前者の表現はエスノサイ エンスあるいはイーミックのレベル，後者の表現 はエティックのレベルとして区別されるが, 将来 は，そうした言葉づかいが土地の人達のものか， それともヨソ者である研究者のものであるのかの 峻別意識が研究者の間で共有されることになろ う.

加えて，イーミックとエティックの 2 つのレベ ルにおける諸表現を，種概念でなく類概念にまと める際に，どういった言葉を用いるべきかという 問題が生じる．最も簡単で最も理に適った表現は もちろん「スポーツ」であるが，「スポーツ」と は異なる(あるいはスポーツの下位概念としての) 表現がスポーツ人類学専門分科会ではこれまでさ まざまに試みられてきた。例えば，民族スポーツ， 伝統スポーツ，民俗競技，祭礼競技，民俗スポー ツ，伝統遊び，民族舞踊，民俗舞踊，祭礼舞踊な どなどである。これらの表現は，それぞれに目的 
をもって使用せられたものであるが，今後どうい った表現を用いるべきか，あるいはどのように使 い分けるべきかが分科会全体で論じられることに なろう。「民族スポーツの概念化」の発表はそう した概念整理の1つの試みといえる.

スポーツ人類学がとり扱う对象は, 子供の遊び や舞踊をも含めた最広義のスポーツであるが，一 般研究発表では, 民族的・伝統的 - 民俗的 - 伝承 的・前近代的・地域限定的な形のものがもっぱら 取り扱われており，これらと対立するオリンピッ クなど国際スポーツ（近代スポーツ）は数件を数 えるばかりである。こうした状況は，スポーツ人 類学は国際スポーツを扱わないとする理解を生み 出すきらいがあるが，スポーツを文化として研究 するというスポーツ人類学の基本的立場からすれ ば，時代と社会を制限せず，国際スポーツも問題 になる．1974年に設立されたアメリカの対応す る学会 The Association for the Anthropological Study of Playでは, 国際スポーツをテーマとす る研究が盛んである。国際スポーツは，民族スポ ーツや民族舞踊と同様，フィールドワークが可能 であるため, 社会学とも協力しながら，その文化 研究を如何に展開するかが分科会の今後の課題と なろう。

一般研究発表にみる对象分析の理論モデルとし て, 身体技法, 文化変容, 文化伝播, 文化領域,
エスノサイエンス，アイデンティティ，文化化, 多文化主義, 観光人類学など文化人類学で開発さ れた理論モデルが多く用いられている。このこと は，スポーツ人類学がスポーツ科学と人類学（と りわけ文化人類学) の学際領域であることに因む もので, 人類学の研究水準と新しい理論モデルを 常時意識することは極めて重要な事柄である。し かし他方で, スポーツ科学に籍をもつことは, 扱 う対象が単にスポーツや遊びや舞踊であるという 一点で保証されるわけではなく，当然そこにはス ポーツ科学に由来する理論モデルや概念の導入が 要請されることになる. スポーツ科学とその前身 たる体育科学・体育学の膨大な知的情報の中から 如何に文化研究のための武器を創り出してゆく か, 今後分科会において検討されることになろう. スポーツ人類学専門分科会は, 海外フィールド ワークと国際学術会議の開催を通して, 特に東ア ジアの国々の体育研究者と交流を重ねてきた。 そ うした交流の成果の 1 つとして，2002 年に韓国ス ポーツ人類学会の設立を見ている。スポーツ人類 学研究の国際ネットワークをどのように築いてゆ くか, 分科会は新しくも魅力的な課題を持つこと になった。

(平成 17 年 1 月 11 日受付 平成 17 年 2 月 19 日受理 